\title{
The Economic Impacts of using Wheat Recommended Technology Package in Al Sharkia Governorate
}

\author{
Hammad Hosni Ahmed El Sayed \\ Agricultural Economics Research Institute, \\ Sami Reda Saber Sabry \\ Agricultural Research Centre; ARC/Egypt
}

\section{Introduction}

Wheat is the most important cereal crop in Egypt due to its importance in the Egyptian diet. Wheat is considered the major staple food commodity for the Egyptian increasing population. The local wheat production does not cover the domestic consumption and consequently, boosting wheat local production is a national goal to narrow the gap between consumption and production and improve food security. This target can be achieved by means of raising the productivity through using the recommended technology packages including using improved agro-techniques and growing high yielding varieties. Besides, among all Egyptian governorates, Al Sharkia Governorate ranks the first in terms of average wheat cultivated area and production (MALR, 2015). Hence, using the package in this Governorate can potentially increase Egypt's production of wheat. It is within this framework that the current study was carried as part of the activities of "Enhancing Food Security in Arab Countries Project (EFSAC-Egypt) - Phase II" jointly implemented by the team of work from the Agricultural Research Centre of Egypt (ARC) and the International Center for Agricultural Research in the Dry Areas (ICARDA).

\subsection{Research problem}

Despite recent impressive gains in local wheat production, Egypt remains the world's largest wheat importer due to increasing wheat domestic consumption resulting in low self-sufficiency and leaving Egyptian food security vulnerable to swings in international wheat prices. Indeed, this situation negatively affects food trade balance. As a result, there is a need to increase the total production of wheat through using the recommended technology package for wheat. These discussions raised some important research questions on:

- How does using the recommended technology package affect the economic efficiency and production function of wheat?;

- How does the dissemination of this package affect the local production of wheat, self-sufficiency of wheat, wheat imports, the cultivated area, water consumption, farmer's income, net agricultural income)?; and

- What do farmers think about using the package and what are the problems they faced?

\subsection{Research objectives}

The study therefore attempts to investigate the current situation of wheat area, productivity, production, consumption and self-sufficiency; measure the impact of using the technology package on the economic efficiency and production function of wheat; estimate the impact of disseminating this package on some economic variables (e.g. the local production of wheat, self-sufficiency of wheat, wheat imports, the cultivated area, water consumption, farmer's income, net agricultural income); and 
Technology Package in Al Sharkia Governorate

finally investigate farmer's perception about using this package and identify the problems they faced.

\section{Methodological Framework}

\subsection{Data source and descriptive analysis}

Surveying procedure and data collection: Data was collected from a socioeconomic survey conducted during winter season of 2014/2015 in Al Sharkia Governorate. A sample of 200 wheat farmers was selected from the target Site (nine districts). Moreover, the target groups were the demonstration farmers (demo farmers) who used the technology package recommended by the Project for three years and their neighboring farmers.

The distribution of respondents across the defined nine districts (clusters) was determined based on the weight proportional importance of the total number of holders in each district. The sample was stratified based on the type of farmers (demo and neighboring), to ensure the representativeness of each type. Interviewed farmers were randomly selected using lists obtained from census offices. The demo farmers represented only a half of the sample.

\subsection{Analytical method}

To reach the objectives of this study, frequency tables representing absolute frequency and relative frequency (or percent) and quantitative methods of analysis were used. Data was also used to estimate wheat production function. Besides, the main indicators of economic efficiency for wheat grown in the study area were calculated. The forms of these indicators are represented in the following formulas:

- Total revenue per ton of grains (in LE) $=$ Total revenue $(\mathrm{LE} / \mathrm{fed}) \div$ Yield of grains (ton/fed)

- Variable costs per ton of grains (in LE) $=$ Variable costs $(\mathrm{LE} / \mathrm{fed}) \div$ Yield of grains (ton/fed)

- Total costs per ton of grains (in $\mathrm{LE})=$ Total costs $(\mathrm{LE} / \mathrm{fed}) \div$ Yield of grains (ton/fed)

- Gross margin per fed (in LE)=Total revenue (LE/fed)-Variable costs (LE/fed)

- Gross margin per ton of grains (in LE) $=$ Gross margin per fed (LE) $\div$ yield of grains (ton/fed)

- Net profit per fed (in LE)=Total revenue (LE/fed)-Total costs (LE/fed)

- Net profit per ton of grains (in LE) $=$ Net profit per fed $(L E) \div Y$ Yeld of grains (ton/fed)

- Benefit/Cost ratio (in LE) $=$ Total Revenue per fed (LE) $\div$ Total Costs per fed (LE)

- Farmer incentive $(\%)=[$ Net profit per ton of grains (LE) $\div$ Farm-gate price of grains (LE/ton)]X100

\section{Results and Discussion}

\subsection{The current situation of wheat production and consumption in Egypt}

Geographical distribution of wheat production: Table 1 showed that the total wheat area cultivated in Al Sharkia, Al Behaira, Al Dakahlia, Kafr El Sheikh, Minya, and Assuit Governorates reached about 1.74 million feddans, representing about 53\% of Egypt's wheat area during the period (2012-2014). Besides, Al Sharkia Governorate ranks the first in terms of average wheat cultivated area and production during that period, reaching about 427 thousand feddans and 1138 thousand tons, 
respectively. This revealed that Al Sharkia Governorate solely contributes to about $12.4 \%$ of the local wheat production.

Table 1: Geographical distribution of wheat grown in Egypt during the period (2012-2014).

\begin{tabular}{|c|c|c|c|c|c|c|}
\hline & \multicolumn{2}{|c|}{ Cultivated Area } & \multicolumn{2}{c|}{ Productivity } & \multicolumn{2}{c|}{ Total Production } \\
\hline Governorate & $\begin{array}{c}\text { Thousand } \\
\text { feddans }\end{array}$ & $\begin{array}{c}\text { \%of } \\
\text { Total }\end{array}$ & Ton/feddan & $\begin{array}{c}\text { Difference from } \\
\text { the Total }\end{array}$ & $\begin{array}{c}\text { Thousand } \\
\text { tons }\end{array}$ & $\begin{array}{c}\text { \% of } \\
\text { Total }\end{array}$ \\
\hline Al Sharkia & $\mathbf{4 2 7}$ & $\mathbf{1 2 . 9}$ & $\mathbf{2 . 6 6}$ & $\mathbf{- 0 . 1 1}$ & $\mathbf{1 1 3 8}$ & $\mathbf{1 2 . 4}$ \\
\hline Al Behaira & 340 & 10.3 & 2.92 & +0.15 & 995 & 10.8 \\
\hline Al Dakahlia & 299 & 9.0 & 2.89 & +0.11 & 863 & 9.4 \\
\hline Kafr El Sheikh & 241 & 7.3 & 2.68 & -0.09 & 645 & 7.0 \\
\hline Minya & 230 & 7.0 & 2.90 & +0.12 & 667 & 7.3 \\
\hline Assuit & 205 & 6.2 & 2.81 & +0.04 & 577 & 6.3 \\
\hline Fayoum & 193 & 5.8 & 2.76 & -0.01 & 534 & 5.8 \\
\hline Sohag & 180 & 5.4 & 2.76 & -0.02 & 496 & 5.4 \\
\hline Al Gharbia & 155 & 4.7 & 2.96 & +0.19 & 459 & 5.0 \\
\hline Beni Seuf & 136 & 4.1 & 2.84 & +0.07 & 387 & 4.2 \\
\hline Menoufia & 136 & 4.1 & 3.24 & +0.47 & 441 & 4.8 \\
\hline Others & 769 & 23.2 & 2.57 & -0.20 & 1976 & 21.6 \\
\hline Total & $\mathbf{3 3 1 1}$ & $\mathbf{1 0 0}$ & $\mathbf{2 . 7 7}$ & $\mathbf{0 . 0 0}$ & $\mathbf{9 1 7 8}$ & $\mathbf{1 0 0}$ \\
\hline
\end{tabular}

Source: compiled and calculated from MALR, (2012-2014).

Cultivated area, productivity and total production of wheat: Table 2 revealed that the area cultivated by wheat in Egypt increased at a statistically significant annual rate of about 71 thousand feddans, representing about $2.5 \%$ of the annual change during this period reaching about 2.88 million feddans during the period (2000-2014). Besides, the total production of wheat in Egypt increased at a significant annual rate of about 198 thousand tons, representing about $2.5 \%$ of the annual change reaching about 7.79 million tons whereas, wheat productivity in Egypt rotated around an average of 2.71 ton/feddan.

At Al Sharkia Governorate, the total area of wheat increased at a statistically significant annual rate of 12 thousand feddans (3.4\% of the annual change) whilst, its total production increased at a statistically significant annual rate of 27 thousand tons $(2.9 \%)$ and wheat productivity reached an average of 2.65 ton/feddan.

Table 2: The progress of some indicators for wheat grown in Egypt and in Al Sharkia Governorate during the period (2000-2014).

\begin{tabular}{|c|c|c|c|c|c|c|}
\hline & & $\underset{(\beta)}{\text { Change }}$ & T-statistic & P-value & $\underset{(\mu)}{\text { Mean }}$ & $\begin{array}{c}\text { Annual } \\
\text { change } \\
(\%)\end{array}$ \\
\hline \multirow{5}{*}{ Egypt } & Cultivated area (thousand feddan) & 71 & $9.2^{*}$ & $4.5 \mathrm{E}-07$ & 2875 & 2.5 \\
\hline & Productivity (ton/feddan) & 0.002 & 0.34 & 0.74 & 2.71 & 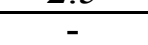 \\
\hline & Production (thousand ton) & 198 & $6.62 *$ & $1.7 \mathrm{E}-05$ & 7788 & 2.5 \\
\hline & Domestic consumption (thousand ton) & 430 & $9.4^{*}$ & $3.5 \mathrm{E}-07$ & 13280 & 3.2 \\
\hline & Self-Sufficiency Rate (SSR) \% & -0.42 & -1.45 & 0.17 & 58.6 & - \\
\hline \multirow{3}{*}{\begin{tabular}{|c|} 
Al \\
Sharkia \\
Gover.
\end{tabular}} & Cultivated area (thousand feddan) & 12 & $6.5^{*}$ & $3.1 \mathrm{E}-08$ & 359 & 3.4 \\
\hline & Productivity (ton) & -0.01 & -1.6 & 0.138 & 2.65 & - \\
\hline & Total production (thousand ton) & 27 & $11.6^{*}$ & $1.9 \mathrm{E}-05$ & 952 & 2.9 \\
\hline
\end{tabular}

Note: $(*)$ indicates statistical significant difference at the $5 \%$ level. (1) calculated as $(\beta \div \mu) \times 100$ Source: compiled and calculated from Table (1) in the annexes.

Domestic consumption and self-sufficiency of wheat: Table 2 illustrated that the domestic consumption of wheat increased at a statistically significant annual rate of about 430 thousand tons, representing about $3.2 \%$ of the annual change reaching about 13.28 million tons during the period (2000-2014) whereas, the self-sufficiency rate of wheat reached an average of $58.6 \%$. 


\subsection{Characteristics of selected sample}

Table 3 revealed that the demo farmers were relatively younger than the neighboring farmers. Besides, about $69 \%$ of the demo farmers got farming experience more than 20 years as compared to about $72 \%$ for the neighboring farmers. The demo farmers were higher-educated than their neighbors. Moreover, about $27 \%$ and $36 \%$ of the demo and neighboring farmers cultivated less than two feddans, respectively whereas, about $55 \%$ and $53 \%$ of them cultivated about $2-5$ feddans, respectively. About $18 \%$ and $11 \%$ of the demo and neighboring farmers cultivated more than five feddans, respectively.

Table 3: Farmer's characteristics in the study sample.

\begin{tabular}{|c|c|c|c|c|c|c|}
\hline \multirow{2}{*}{ Characteristics } & \multicolumn{2}{|c|}{ Demo Farmers } & Neighboring Farmers & \multicolumn{2}{c|}{ Overall } \\
\cline { 2 - 7 } & Frequency & $\%$ & Frequency & $\%$ & Frequency & $\%$ \\
\hline Age & $\mathbf{1 0 0}$ & $\mathbf{1 0 0}$ & $\mathbf{1 0 0}$ & $\mathbf{1 0 0}$ & $\mathbf{2 0 0}$ & $\mathbf{1 0 0}$ \\
\hline $\mathbf{4 5}$ years & 12 & 12 & 9 & 9 & 21 & 10.5 \\
\hline $\mathbf{4 5}-\mathbf{5 5}$ years & 39 & 39 & 24 & 24 & 63 & 31.5 \\
\hline$>\mathbf{5 5}$ years & 49 & 49 & 67 & 67 & 116 & 58.0 \\
\hline Farming Experience & $\mathbf{1 0 0}$ & $\mathbf{1 0 0}$ & $\mathbf{1 0 0}$ & $\mathbf{1 0 0}$ & $\mathbf{2 0 0}$ & $\mathbf{1 0 0}$ \\
\hline < 20 years & 31 & 31 & 28 & 28 & 59 & 29.5 \\
\hline $\mathbf{2 0}-\mathbf{3 0}$ years & 20 & 20 & 47 & 47 & 67 & 33.5 \\
\hline$>$ 30 years & 49 & 49 & 25 & 25 & 74 & 37.0 \\
\hline Level of Education & $\mathbf{1 0 0}$ & $\mathbf{1 0 0}$ & $\mathbf{1 0 0}$ & $\mathbf{1 0 0}$ & $\mathbf{2 0 0}$ & $\mathbf{1 0 0}$ \\
\hline Illiterate & 15 & 15 & 30 & 30 & 45 & 22.5 \\
\hline Can Read \& Write & 37 & 37 & 26 & 26 & 63 & 31.5 \\
\hline Prim. \& Prep. School & 2 & 2 & 1 & 1 & 3 & 1.5 \\
\hline High School Graduates & 19 & 19 & 25 & 25 & 44 & 22 \\
\hline University Graduates & 27 & 27 & 18 & 18 & 45 & 22.5 \\
\hline Farm Size & $\mathbf{1 0 0}$ & $\mathbf{1 0 0}$ & $\mathbf{1 0 0}$ & $\mathbf{1 0 0}$ & $\mathbf{2 0 0}$ & $\mathbf{1 0 0}$ \\
\hline < 2 feddan & 27 & 27 & 36 & 36 & 63 & 31.5 \\
\hline 2 - 5 feddan & 55 & 55 & 53 & 53 & 108 & 54 \\
\hline$>\mathbf{5}$ feddan & 18 & 18 & 11 & 11 & 29 & 14.5 \\
\hline
\end{tabular}

Source: The results of the survey 2014/2015.

\subsection{The components of the recommended technology package}

The components of the technology package recommended by the Project (Phase I) for wheat in Al Sharkia Governorate included using improved wheat varieties, seed rate $(45 \mathrm{~kg} / \mathrm{fed})$, planting date (15-30 November), planting method (raised-bed with different types), nitrogenous fertilization $(75 \mathrm{~kg} / \mathrm{fed})$, and phosphate fertilization (15 $\mathrm{kg} / \mathrm{fed}$ ).

3.4. The impact of using the recommended technology package on the indicators of economic efficiency for wheat grown in the study area

Yield: Table 4 showed statistical significant effect of using the recommended technology package on the yield of wheat grown in the study Site. The average grain yield of wheat for the demo farmers exceeds that cultivated by their neighbors by about $11.3 \%$ since it reached about 3.50 and 3.15 ton/fed for both types of farmers, respectively.

Costs of production: The results showed statistical significant effect of using the package on the variable and total costs for wheat grown in the demo and neighboring farms. The variable and total costs of wheat grown in the demo farms were relatively higher than that for the neighbors by about $3.3 \%$ and $2.1 \%$, respectively (Table 4).

Total revenue per feddan: Our findings revealed that using the package significantly affected the total revenue of wheat since the demo farms gained about LE 1055 exceeding that gained by their neighbors (10.5\%) due to getting higher yield, indicating that demo farmers gained more profits in terms of this indicator. 
Gross margin per feddan: Based on Table 4, using the package has a significant positive effect on the gross margin of wheat in favour of the demo farmers since they gained about LE 870 exceeding that gained by their neighbors, representing about $19.8 \%$ over that gained by the neighbors, indicating that demo farmers gained more profits.

Net profit per feddan: Table 4 showed that using the package significantly affected the net profit of wheat since the demo farms gained about LE 870 exceeding that gained by the neighbors $(75.0 \%)$, indicating that demo farmers gained more profits.

Variable and total costs per ton of grains: Table 4 revealed that using the recommended package significantly affected the variable and total costs per ton of wheat grains in favour of the demo farmers since these costs were lower for the demo farms than that of their neighbors by about $7.8 \%$ and $8.9 \%$, respectively, indicating that demo farmers gained more profits in terms of this indicator.

Total revenue per ton of grains: Our results showed statistical significant effect of using the package on the total revenue per ton of wheat grains in the demo and neighboring farms. The total revenue per ton of wheat grains in the demo farms were relatively lower than that for the neighbors by about $0.8 \%$ (Table 4 ).

Gross margin per ton of grains: The results revealed that using the package has a significant positive effect on the gross margin per ton of wheat grains in favour of the demo farmers since they gained about $8.5 \%$ over that gained by the neighbors, indicating that demo farmers gained more profits in terms of this indicator (Table 4).

The percentage of farmer incentive: Table 4 indicated that using the package significantly affected the percentage of farmer incentive of wheat was in favour of the demo farmers since they gained about $66 \%$ exceeding that gained by the neighbors, indicating that demo farmers gained more profits in terms of this indicator.

Table 4: Indicators of economic efficiency of wheat grown in the study area.

\begin{tabular}{|c|c|c|c|c|c|}
\hline \multirow{2}{*}{ Indicator } & \multirow{2}{*}{\begin{tabular}{|c|} 
Demo \\
Farmers
\end{tabular}} & \multirow{2}{*}{$\begin{array}{c}\text { Neighboring } \\
\text { Farmers }\end{array}$} & \multicolumn{2}{|c|}{ Change } & \multirow{2}{*}{$\begin{array}{c}\mathrm{T}- \\
\text { statistic }\end{array}$} \\
\hline & & & Value & $(\%)$ & \\
\hline Grain yield (ton/fed.) & 3.502 & 3.148 & +0.354 & 11.3 & $9.4^{*}$ \\
\hline Farm-gate Price (LE/ton of grains) & 2749 & 2749 & 0 & 0 & \\
\hline Straw yield (ton/fed.) & 3.003 & 2.837 & +0.166 & 5.8 & $2.96^{*}$ \\
\hline Farm-gate Price (LE/ton of straw) & 489 & 489 & 0 & 0 & \\
\hline Total Revenue per fed. (LE) & 11095 & 10040 & +1055 & 10.5 & $9.99 *$ \\
\hline Fixed Costs (LE/fed.) & 3221 & 3221 & 0 & 0 & \\
\hline Variable Costs (LE/fed.) & 5846 & 5660 & +186 & 3.3 & $3.6^{*}$ \\
\hline Total Costs (LE/fed.) & 9067 & 8881 & +186 & 2.1 & $3.6^{*}$ \\
\hline Gross Margin per fed. (LE) & 5249 & 4380 & +869 & 19.8 & $7.4^{*}$ \\
\hline Net Profit per fed. (LE) & 2029 & 1159 & +869 & 75 & $7.4^{*}$ \\
\hline Variable Costs per ton of grains (LE) & 1673 & 1815 & -142 & -7.8 & $-5.5^{*}$ \\
\hline Total Costs per ton of grains (LE) & 2596 & 2848 & -25.2 & -8.9 & $-7.4 *$ \\
\hline Total Revenue per ton of grains (LE) & 3170 & 3194 & -24 & -0.8 & $-3.2^{*}$ \\
\hline Gross Margin per ton of grains (LE) & 1497 & 1379 & +118 & 8.5 & $4.8^{*}$ \\
\hline Farmer Inc & 20.9 & 12.6 & +8.3 & 66 & $7.0^{*}$ \\
\hline Net Profit per ton of grains (LE) & 574 & 346 & +228 & 66 & $7.0^{*}$ \\
\hline Benefit/Cost Ratio (LE) & 1.23 & 1.13 & +0.09 & 8.2 & $6.7^{*}$ \\
\hline
\end{tabular}

Note: $(*)$ indicates statistical significant difference at the $5 \%$ level.

Source: The results of the survey 2014/2015.

Net profit per ton of grains: Our findings showed that using the package has a significant positive effect on the net profit per ton of wheat grains in favour of the 
demo farmers since they gained about $66 \%$ over that gained by the neighbors, indicating that demo farmers gained more profits in terms of this indicator (Table 4).

Benefit/Cost ratio (B/C) per feddan: Based on Table 4, using the package has a significant positive effect on the $\mathrm{B} / \mathrm{C}$ of wheat in favour of the demo farmers, gaining about $8.2 \%$ over that gained by the neighbors, making more profits by the demo farmers.

\subsection{The impact of using the recommended technology package on the production function of wheat grown in the study area}

Data was also used to estimate wheat production function. The production function was specified using a range of variables including seeds, organic manure, chemical fertilizers and labour, and estimated with a set of functional forms including linear, log-linear, log-log (Cobb-Douglas) and quadratic. The functional form that had the best fit for the given data set was estimated with a set of independent variables as given below:

$\operatorname{LnY}_{i}=b_{0}+\mathbf{a D}+b_{1} \operatorname{Ln}\left(X_{1 i}\right)+b_{2} \operatorname{Ln}\left(X_{2 i}\right)+b_{3} \operatorname{Ln}\left(X_{3 i}\right)+b_{4} \operatorname{Ln}\left(X_{4 i}\right)+b_{5} \operatorname{Ln}\left(X_{5 i}\right)+U_{i}$ where:

Y: the yields of wheat (ton/feddan);

$\mathrm{D}$ : dummy variable for using the recommended technology package $(\mathrm{D}=1$ if using, $\mathrm{D}_{\mathrm{t}}=0$ otherwise);

$\mathrm{X}_{1}$ : quantity of seeds in $\mathrm{kg} /$ feddan;

$\mathrm{X}_{2}$ : quantity of organic manure in $\mathrm{CM} /$ feddan;

$\mathrm{X}_{3}$ : quantity of nitrogenous fertilizers in $\mathrm{kg} /$ feddan;

$\mathrm{X}_{4}$ : quantity of phosphorus fertilizers in $\mathrm{kg} /$ feddan;

$\mathrm{X}_{5}$ : labour (man-day/feddan);

i: denotes farm; $\quad$ a and $b_{s}$ : coefficients to be estimated; $\quad U$ : error term.

The estimation results of wheat production function are portrayed in Table 5. The F-value showed statically significance at the 5\% level, implying statistical significant positive effect of using the recommended technology package on the yield of wheat grown in the demo farms, as compared to their neighbors in the study Site. Besides, among the range of factors that could possibly affect wheat production, using the package, seeds, chemical nitrogenous fertilizers, and labour are statically significant in the determination of wheat production. However, the positive signs of the coefficients of using the recommended package, nitrogenous fertilizers, and labour indicate that these factors positively affect wheat production function whereas, seed rate (with a negative coefficient) negatively affects wheat production. The primary reason for this negative effect is that the neighboring farmers used larger rate of seeds than the recommended level (for example, owing to late cultivation of wheat), implying that using the recommended seed rate positively affects wheat production. Contrariwise, using organic manure and phosphorus fertilizers have statically insignificant effect on wheat production since it is recommended to use them based on the soil properties.

Furthermore, the elasticity of production is estimated at about 0.38 , implying diminishing rates of returns. The adjusted coefficient of determination (adj. $R^{2}$ ) indicated that the studied factors of wheat production explain $91 \%$ of the variation in 
the wheat production whereas, the rest $(9 \%)$ represents other factors not included in the estimated production function of wheat in the study area such as wheat losses due to pest and/or disease attacks and/or spillage.

Table 5: Estimates of the production functions for wheat grown in the study area

\begin{tabular}{|c|c|c|c|}
\hline & Coefficient & T-statistic & P-value \\
\hline Constant & 0.218 & $6.32^{*}$ & \\
\hline D & 0.189 & $3.952 *$ & 0.00011 \\
\hline $\mathrm{X}_{1}(\mathrm{~kg} / \mathrm{fed})$ & -0.113 & $-2.015^{*}$ & 0.04531 \\
\hline $\mathbf{X}_{2}\left(\mathbf{m}^{3} / \mathrm{fed}\right)$ & 0.025 & 1.909 & 0.05782 \\
\hline $\mathrm{X}_{3}(\mathrm{~kg} / \mathrm{fed})$ & 0.106 & $2.023^{*}$ & 0.04446 \\
\hline$X_{4}(\mathrm{~kg} / \mathrm{fed})$ & 0.012 & 0.441 & 0.65943 \\
\hline$X_{5}($ man-day/fed $)$ & 0.160 & $2.763^{*}$ & 0.00629 \\
\hline F-value & \multirow{2}{*}{\multicolumn{3}{|c|}{$\begin{array}{l}573^{*} \\
0.91\end{array}$}} \\
\hline Adj. R & & & \\
\hline$E_{P}$ (Elasticity of Production) & \multirow{2}{*}{\multicolumn{3}{|c|}{$\frac{0.38}{200}$}} \\
\hline n & & & \\
\hline
\end{tabular}

Note: (*) indicates statistical significant difference at the $5 \%$ level.

Source: The results of the socio-economic farm and household survey 2014/2015.

3.6. The impact of using the recommended technology package on some economic variables of wheat grown in Al Sharkia Governorate and nationwide

Based on the results revealed by the study, Table 6 revealed that the dissemination of the recommended technology package on wheat produced in $\mathrm{Al}$ Sharkia Governorate and over-all Egypt can potentially increase wheat production by about 151 thousand tons in the Governorate and by about 1172 thousand tons at the national level, representing about $12.77 \%$ over the production of wheat achieved during the period (2012-2014). This means boosting the local production of wheat to reach about 10.35 million tons nation-wide as compared to the average local production of wheat of about 9.18 million tons achieved during that period thus, releasing an agricultural area of about 335 thousand feddans, representing about $10.11 \%$ of the area that was cultivated by wheat during the study period and saving about 630 million cubic meters of irrigation water. However, the released area can be cultivated by other winter crops (e.g. faba bean or lintels) whereas, the saved water can be used to irrigate other areas or winter crops. This in turn, raises the selfsufficiency rate of wheat from about $54.06 \%$ achieved during that period to about $59.53 \%$ and reduces the value of wheat imports by about USD 0.91 billion from about USD 2.80 billion during the period (2012-2014) to only about USD 1.89 billion, representing about $32.56 \%$ less than the average value of wheat imports for the study period thus, positively affecting the deficit in the agricultural trade balance.

Table 6: The impact of using the recommended technology package on some economic variables of wheat grown in Al Sharkia Governorate and nationwide.

\begin{tabular}{|c|c|c|c|c|c|c|c|c|c|c|}
\hline \multicolumn{3}{|c|}{$\begin{array}{l}\text { The increase of local } \\
\text { production }\end{array}$} & \multirow{2}{*}{\multicolumn{2}{|c|}{$\begin{array}{c}\text { The released } \\
\text { cultivated } \\
\text { area }\end{array}$}} & \multirow{3}{*}{$\begin{array}{c}\text { Self- } \\
\text { Sufficiency } \\
\text { Rate } \\
\text { (SSR)\% } \\
\text { (4) }\end{array}$} & \multirow{2}{*}{\multicolumn{2}{|c|}{$\begin{array}{l}\text { The reduction } \\
\text { of imports }\end{array}$}} & \multicolumn{3}{|c|}{$\begin{array}{l}\text { The increase of net } \\
\text { agricultural income }\end{array}$} \\
\hline $\begin{array}{l}\text { Al Sharkia } \\
\text { G. }^{(1)}\end{array}$ & Egypt & & & & & & & $\begin{array}{c}\text { Al Sharkia } \\
\text { G. }{ }^{(1)}\end{array}$ & Egyp & \\
\hline $\begin{array}{l}\text { Quantity } \\
\text { (000 ton) }\end{array}$ & $\left|\begin{array}{l}\text { Quantity } \\
\text { (000 ton) }\end{array}\right|$ & $\%$ & $\begin{array}{l}\text { Area } \\
(000 \\
\text { fed) }\end{array}$ & $\%^{(3)}$ & & $\begin{array}{c}\text { Value } \\
\text { (million } \\
\$ \text { ) }\end{array}$ & $\%^{(5)}$ & $\begin{array}{c}\text { Value } \\
\text { (million } \\
\text { LE) }\end{array}$ & $\begin{array}{c}\text { Value } \\
\text { (million } \\
\text { LE) }\end{array}$ & $\%^{(6)}$ \\
\hline 151 & 1172 & 12.77 & 335 & 10.11 & 59.53 & 910.70 & 32.56 & 371 & 2877 & 1.40 \\
\hline
\end{tabular}

Source: compiled and calculated from: Table 4; CAPMAS, 2015; COMTRADE, 2015; MALR, 2015 and $b$. 
Besides, the dissemination of this technology package on wheat increases the net revenue of wheat thus, enhancing the income earned by wheat farmers in Al Sharkia Governorate by about L.E. 371 million, and increasing Egypt's net agricultural income by about L.E. 2877 million, representing about 1.40\% over Egypt's net agricultural income for the study period of about LE 371 billion.

\subsection{Farmer's perception about using the recommended technology package}

The demo farmers were asked about their perception after using the recommended technology package. The results showed that the demo farmers reported that the package was useful due to achieving high yield and high quality of grains, saving irrigation time and costs, saving seeds, easy weeding, saving chemical fertilizers, and disease-resistance (e.g. powdery mildew). However, some of the demo farmers skipped some components of the recommended technology package due to low soil fertility and getting insufficient irrigation water supply since their farms are located at the tail-end of the mesqa.

Table 7: Responds of the demo farmers about using the recommended technology package for wheat (\%).

\begin{tabular}{|l|l|}
\hline & $\%$ \\
\hline High yielding & 100 \\
\hline High quality of grains & 98 \\
\hline Saving irrigation time and costs & 95 \\
\hline Saving seeds & 89 \\
\hline Easy weeding & 30 \\
\hline Saving chemical fertilizers & 28 \\
\hline Disease-resistance (e.g. powdery mildew) & 17 \\
\hline
\end{tabular}

Source: The results of the survey 2014/2015.

3.8. Farmer's opinion about the main problems they faced while using the recommended technology package

The main problems they faced while using this package were unavailability of raised-bed machines, high costs of production, lack of regular maintenance for the raised-bed machines, lack of chemical fertilizers, poor distribution of wheat improved seeds, and lack of good pesticides (Table 8).

Table 8: Responds of the demo farmers about the problems they faced while using the recommended technology package for wheat.

\begin{tabular}{|l|l|}
\hline & $\%$ \\
\hline Unavailability of the raised-bed machines & 47 \\
\hline High costs of production & 37 \\
\hline Lack of regular maintenance for the raised-bed machines & 11 \\
\hline Lack of chemical fertilizers & 7 \\
\hline Poor distribution of improved seeds & 3 \\
\hline Lack of good pesticides & 1 \\
\hline
\end{tabular}

Source: The results of the survey 2014/2015.

\section{Concluding remarks, recommendations and policy implications}

The primary objectives of this study are to measure the economic impacts of using the recommended technology package of wheat in Al Sharkia Governorate, investigate farmer's perception about using this package, and identify the problems they faced. To reach these objectives, the methodology used was based on the 
calculation of different economic indicators and the production function for wheat grown in the study area using a 200-farmers socio-economic survey conducted during winter season of 2014/2015 in Al Sharkia Governorate. The target groups were the demonstration farmers (demo farmers) who used the technology package recommended by the Project for three years (100 farmers) and their neighboring farmers (100 farmers).

Our findings revealed that the average grain yield of wheat for the demo farmers exceeds that cultivated by their neighbors by about $11.3 \%$ since it reached about 3.50 and 3.15 ton/fed for both types of farmers, respectively and the demo farmers gained more profits in terms of all of the economic efficiency indicators. Besides, the results showed statistical significant positive effect of using the recommended technology package on the production function of wheat grown in the demo farms in the study area. Moreover, disseminating this package has positive potential effect on increasing the local production of wheat, saving irrigation water, raising the self-sufficiency rate of wheat, reducing wheat imports, enhancing the incomes of wheat producers in Al Sharkia Governorate, and increasing Egypt's net agricultural income.

These results confirm that the recommended technology package of wheat is a potential, not only to boost the local production of wheat but also to enhance the incomes of wheat producers in the study area. The demo farmers reported that the package was useful due to achieving high yield and high quality of grains, saving irrigation time and costs, saving seeds, easy weeding, saving chemical fertilizers, and disease-resistance. Therefore, farmers are encouraged to the recommended technology package of wheat in Al Sharkia Governorate. However, the main problems they faced while using this package were lack of raised-bed machines, high costs of production, lack of skilled labour, lack of regular maintenance for the raisedbed machines, lack of chemical fertilizers, and unavailability of wheat improved seeds.

Thus, the study recommends sufficient farmer's access to knowledge and improving communication channels between farmers and agricultural extension and skilled extension personnel to transfer and disseminate the recommended technology package of wheat in Al Sharkia Governorate; re-activating the role of mechanical service stations and agricultural co-operatives by providing them with raised-bed machines; training agricultural extension personnel on operation and maintenance of the raised-bed machines; and providing agricultural co-operatives with adequate seeds of improved wheat varieties at suitable time and affordable prices.

Finally, these recommendations are supported not only by our findings but also by the objectives of the National Agricultural Sustainable Development Strategy 2030 targeting promoting self-sufficiency of the strategic food commodities, reducing poverty rates in the rural areas, and rationalizing water and land use through the introduction of new high-yielding drought-tolerant varieties, introduction of agricultural management technology package in order to improve agricultural production systems (MALR, 2009). 


\section{References:}

- Abdin, A. E. et al, (2009). Rational water use in Egypt, Technological Perspectives for Rational Use of Water Resources in the Mediterranean Region, CIHEAM. p. 11-27, Options Méditerranéennes: Série B. Etudes et Researches; n. 88, Bari.

- Hoevenaars, J. and Slootweg, R., (2004). Towards Integrated Planning of Irrigation and Drainage in Egypt-In support of the IIIMP: Rapid Assessment Study Towards Integrated Planning of Irrigation and Drainage in Egypt-Natural Resources Perspective.

- CAPMAS, (2015). The Statistical Year Book 2012-2014. Cairo, Egypt: Central Agency for Public Mobilization and Statistics (CAPMAS).

- COMTRADE, (2015). The United Nations Commodity Trade Statistics Database (comtrade.un.org).

- Johston, J., (1972). Economic Methods. Second Edition. Mc Graw Hill Books, New York.

- MALR, (2009). Sustainable Agricultural Development Strategy towards 2030 (SADS). 2009. Agricultural Research and Development Council, Arab Republic of Egypt, Ministry of Agriculture and Land Reclamation.

- MALR. (2015 a). Bulletin of Agricultural Statistics 2000-2014. Economic Affairs Sector, Central Department of Agrarian Economics \& Statistics. Cairo, Egypt: Ministry of Agriculture and Land Reclamation (MALR).

- MALR. (2015 b). Bulletin of Agricultural Income 2012-2014. Economic Affairs Sector, Central Department of Agrarian Economics \& Statistics. Cairo, Egypt: Ministry of Agriculture and Land Reclamation (MALR).

- Sultan, Y. M.; and Dosoky A. M., (1999). Economic Study on the Effect of the Technological Package of Wheat Production in Sohag. The 7th Conference of Agricultural Economists on Technology and Agriculture in the 21st Century, Egyptian Association of Agricultural Economics, Cairo, Egypt.

- NCUWPE, (2014). Annual Reports of the National Campaign to Upraise Wheat Production in Egypt (NCUWPE), 2011/2012, 2012/2013 and 2013/2014.

\section{Annexes:}

Annex 1: The progress of some indicators for wheat grown in Egypt and in Al Sharkia Governorate during the period (2000-2014).

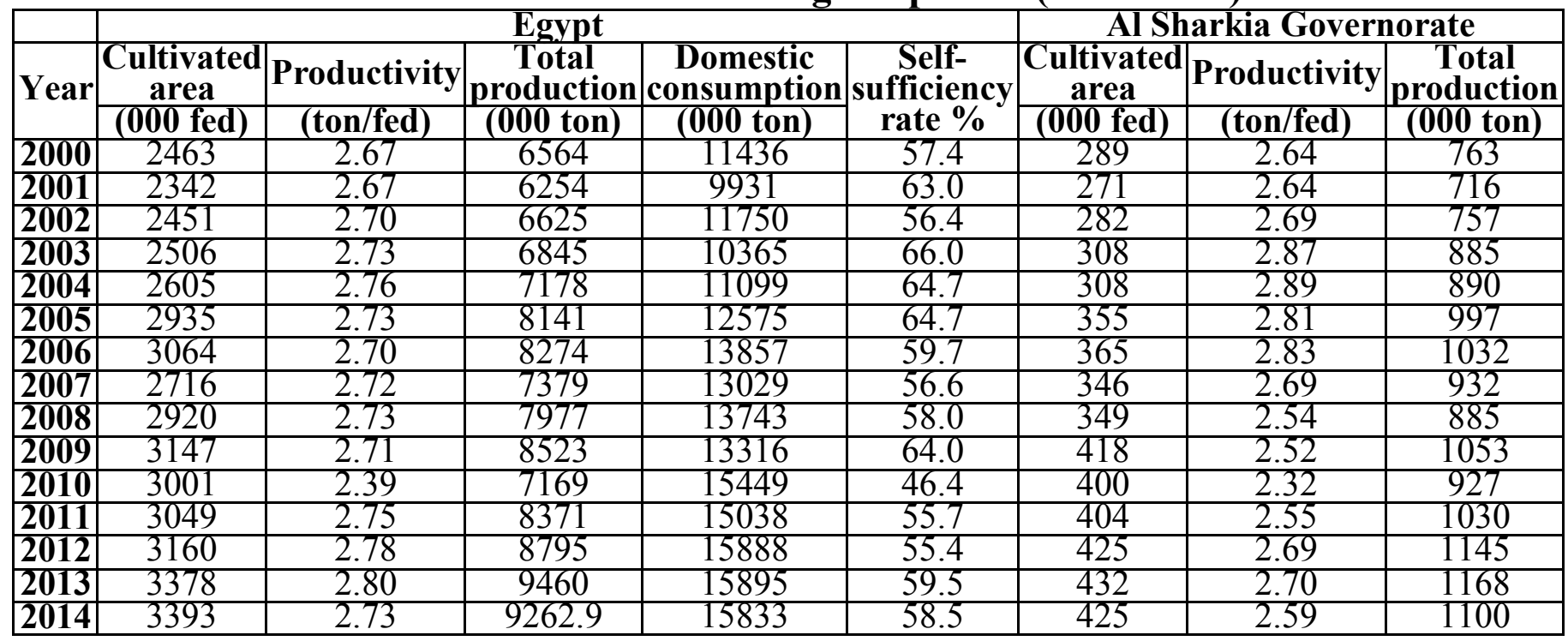

Source: www.msrintranet.capmas.gov.eg and MALR. (2015 a). 


\section{Technology Package in Al Sharkia Governorate}

الآثار الاقتصادية لاستخدام الحزمة التكنولوجية الموصى بها

\section{لمحصول القمح في محافظة الشرقية}

أ.د أدامي رضا صابر صبري

معه بحوث المحاصيل الحقلية - مركز البحوث الزراعية.
د/ حماد حني أحمد السيد

معهل بحوث الاقتصاد الزراعي - مركز البحوث الزراعية

الملخص

يُعد محصول القمح من أهم محاصيل الحبوب في النمط الغذائي المصري ، لذا تولي الدولة اهتماماً

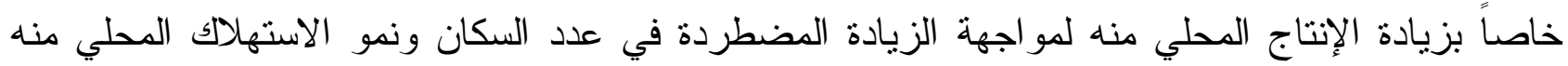
ومن ثم زيادة الكميات المستوردة منه لتغطية العجز بين الإنتاج المحلي والاستهلالك المحلي من هذا

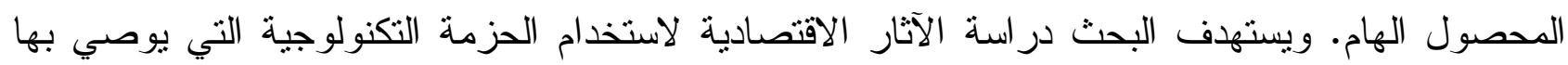

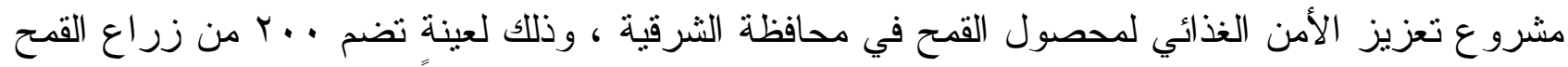

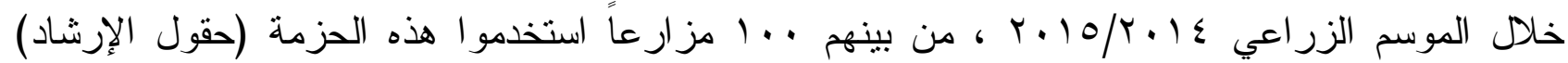
و . . ا مز ارعاً لم يستخدمو ا هذه الحزمة خلال ذات الموسم (حقول المقارنة).

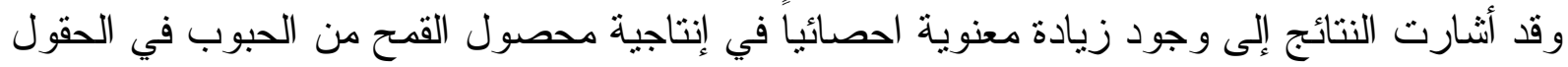
الارشادية تُقدر بنحو r,11\% فوق الإتتاجية المحققة في حقول المقارنة ، وهو ما انعكس إيجابياً على تحقيق

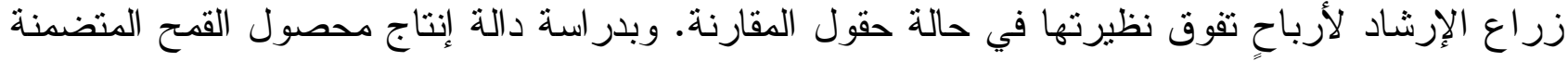
متغير صوري لاستخدام الحزمة التكنولوجية الموصى بها ، فقد ثتتت المعنوية الإحصائية لأثر تطبيق الحزمة التكنولوجية على إنتاجية المحصول. وتبين أن تعميم استخدام الحزمة التكنولوجية الموصى بها لمحصول القمح في محافظة الثرقية وعلى مستوى الجمهورية يحقق زيادة في الإتتاج المحلي من هذا المحصول على مستوى المحافظة وعلى المستوى فئى

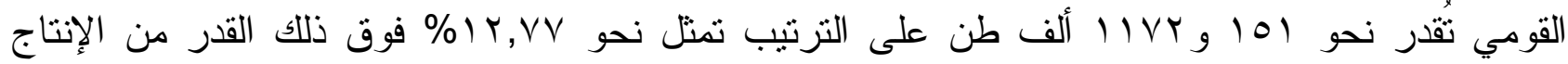

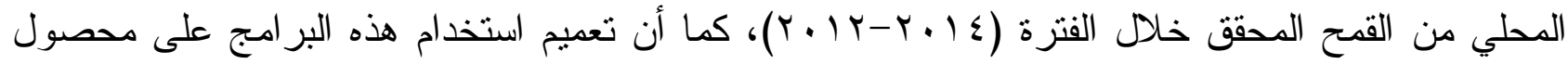
القمح بالمحافظة وعلى مستوى الجمهورية يحقق وفراً في المساحة المزروعة بهذا المئا المحصول نتيجة تحقيق

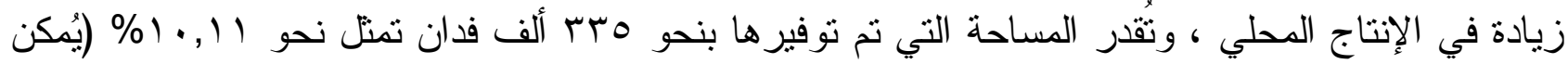
زر اعتها بمحاصيل شتوية أخرى كالفول البلدي و العدس) ، ويحقق ذللك وفراً في كمية مياه الري العي الدستخدمة

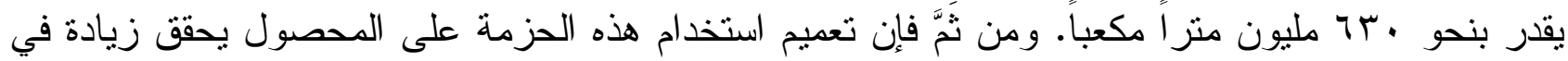

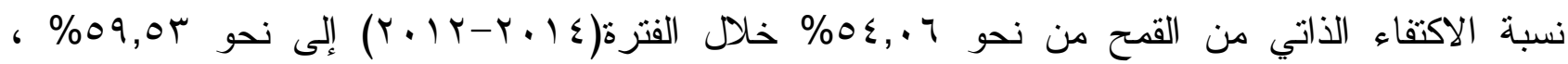

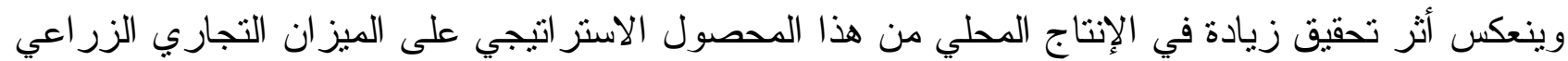

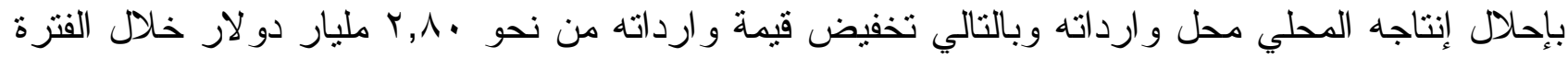

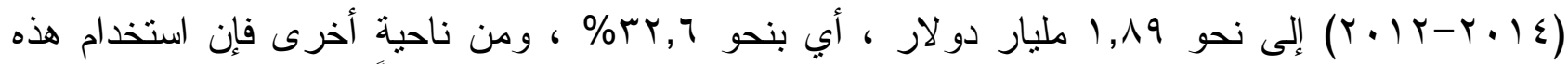
الحزمة يؤدي إلى زيادة صافي العائد الفداني منه وتحسين دخول الزراع بالئ بالمحافظة ورفع مستوى معيشتهم

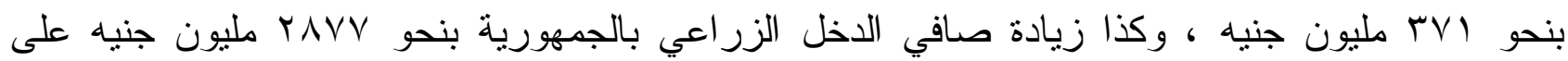

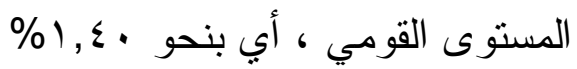


المجلة المصرية للاقتصاد الزراعي - المجلا السادس والعشرون - العدد الأول - مارس 17 بـ بـ

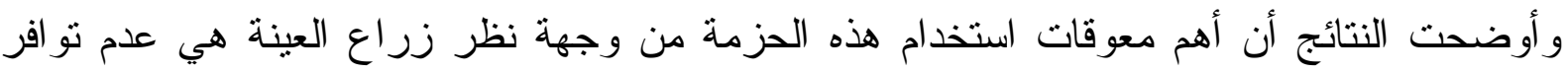
ماكينات المصاطب العريضة ، ارتفاع تكاليف الإنتاج ، وعدم نو افر العمالة المدربة على تتغغيل وصيانة هذه

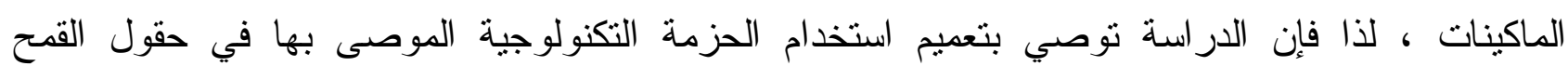

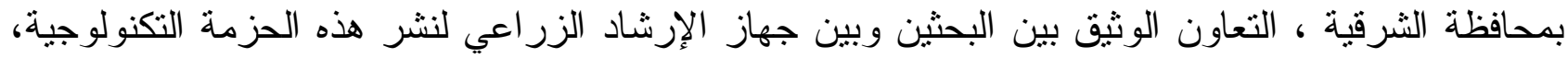

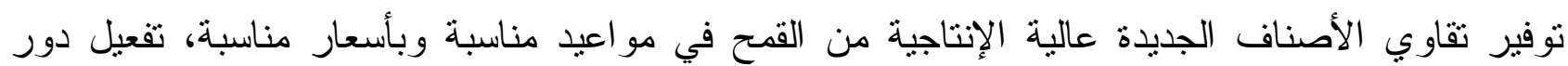
محطات الخدمة الآلية و الجمعيات التعاونية الزر اعية من خلال تزويدها بماكينات المصاطب الإنية العريضة بأعداد

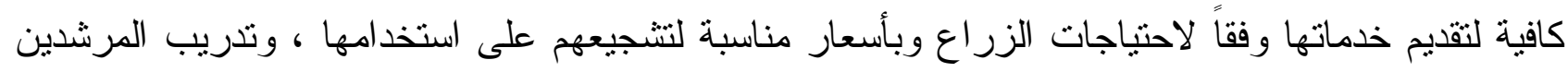
الزر اعيين على تشغيل وصيانة هذه الماكينات. 